\title{
Front Matter: Volume 9705
}

, "Front Matter: Volume 9705," Proc. SPIE 9705, Microfluidics, BioMEMS, and Medical Microsystems XIV, 970501 (6 May 2016); doi: 10.1117/12.2229266

SPIE. Event: SPIE BiOS, 2016, San Francisco, California, United States 


\title{
PROGRESS IN BIOMEDICAL OPTICS AND IMAGING

\section{Microfluidics, BioMEMS, and Medical Microsystems XIV}

\author{
Bonnie L. Gray \\ Holger Becker \\ Editors
}

13-15 February 2016

San Francisco, California, United States

Sponsored by

SPIE

Cosponsored by

microfluidic ChipShop GmbH (Germany)

The Ohio Center for Microfluidic Innovation at the University of Cincinnati (United States)

Published by

SPIE 
The papers in this volume were part of the technical conference cited on the cover and title page. Papers were selected and subject to review by the editors and conference program committee. Some conference presentations may not be available for publication. Additional papers and presentation recordings may be available online in the SPIE Digital Library at SPIEDigitallibrary.org.

The papers reflect the work and thoughts of the authors and are published herein as submitted. The publisher is not responsible for the validity of the information or for any outcomes resulting from reliance thereon.

Please use the following format to cite material from these proceedings:

Author(s), "Title of Paper," in Microfluidics, BioMEMS, and Medical Microsystems XIV, edited by Bonnie L. Gray, Holger Becker, Proceedings of SPIE Vol. 9705 (SPIE, Bellingham, WA, 2016) Six-digit Article CID Number.

ISSN: 1605-7422

ISSN: 2410-9045 (electronic)

ISBN: 9781628419399

Published by

SPIE

P.O. Box 10, Bellingham, Washington 98227-0010 USA

Telephone +1 3606763290 (Pacific Time) · Fax +1 3606471445

SPIE.org

Copyright (C) 2016, Society of Photo-Optical Instrumentation Engineers.

Copying of material in this book for internal or personal use, or for the internal or personal use of specific clients, beyond the fair use provisions granted by the U.S. Copyright Law is authorized by SPIE subject to payment of copying fees. The Transactional Reporting Service base fee for this volume is $\$ 18.00$ per article (or portion thereof), which should be paid directly to the Copyright Clearance Center (CCC), 222 Rosewood Drive, Danvers, MA 01923. Payment may also be made electronically through CCC Online at copyright.com. Other copying for republication, resale, advertising or promotion, or any form of systematic or multiple reproduction of any material in this book is prohibited except with permission in writing from the publisher. The CCC fee code is $2410-9045 / 16 / \$ 18.00$.

Printed in the United States of America.

Publication of record for individual papers is online in the SPIE Digital Library.

\section{SPIE. DIGITAL}

Paper Numbering: Proceedings of SPIE follow an e-First publication model. A unique citation identifier (CID) number is assigned to each article at the time of publication. Utilization of CIDs allows articles to be fully citable as soon as they are published online, and connects the same identifier to all online and print versions of the publication. SPIE uses a six-digit CID article numbering system structured as follows:

- The first four digits correspond to the SPIE volume number.

- The last two digits indicate publication order within the volume using a Base 36 numbering system employing both numerals and letters. These two-number sets start with $00,01,02,03,04$, $05,06,07,08,09,0 A, 0 B \ldots$ OZ, followed by 10-1Z, 20-2Z, etc. The CID Number appears on each page of the manuscript. 


\title{
Contents
}

\author{
vii Authors \\ ix Conference Committee \\ xi Introduction
}

\section{SESSION 1 MICROFLUIDIC DEVICES I}

970502 Dean flow fractionation of chromosomes (Invited Paper) [9705-1]

970503 A latchable thermally activated phase change actuator for microfluidic systems [9705-2]

970504 Improved optical resolution for elastomer-liquid lens at high diopter using varied thickness membrane [9705-3]

970505 One-layer microfluidic device for hydrodynamic 3D self-flow-focusing operating in low flow speed [9705-4]

\section{SESSION 2 MANUFACTURING I}

970507 Tacky COC: a solvent bonding technique for fabrication of microfluidic systems [9705-6]

970508 Electrowetting liquid lens array on curved substrates for wide field of view image sensor [9705-7]

970509 Transfer molding processes for nanoscale patterning of poly-L-lactic acid (PLLA) films (Best Student Paper Award) [9705-8]

\section{SESSION 3 MICROFLUIDIC DEVICES II}

9705 OC Low-cost implementation of acoustophoretic devices (Invited Paper) [9705-11]

9705 OD Photothermal generation of microbubbles on plasmonic nanostructures inside microfluidic channels [9705-12]

$9705 \mathrm{OE}$ The use of microfluidics and dielectrophoresis for separation, concentration, and identification of bacteria [9705-13]

9705 OF Blister pouches for effective reagent storage and release for low cost point-of-care diagnostic applications [9705-14] 
9705 OG Advances towards reliable identification and concentration determination of rare cells in peripheral blood (Invited Paper) [9705-15]

$9705 \mathrm{OH} \quad$ Novel microfluidic system for online monitoring of biofilm dynamics by electrical impedance spectroscopy and amperometry [9705-16]

\section{SESSION 5 MANUFACTURING II}

9705 0J Microfluidic vascular channels in gels using commercial 3D printers (Invited Paper) [9705-19]

9705 OL Pyro-EHD ink-jet printing for direct functionalization of 3D lab-on-chip devices [9705-22]

9705 OM Enhancing defect tolerance in periodic post microfluidic channels [9705-23]

9705 ON Maskless fabrication of a microfluidic device with interdigitated electrodes on PCB using laser ablation [9705-21]

\section{SESSION 6 OPTOFLUIDICS}

970500 Silicon chip integrated photonic sensors for biological and chemical sensing (Invited Paper) [9705-24]

9705 OP Adaptive optofluidic lens(es) for switchable 2D and 3D imaging [9705-25]

$97050 Q \quad$ Integrating optopiezoelectric actuators and a two-mode excited linear ultrasonic motor for microfluidics [9705-26]

\section{SESSION 7 APPLICATIONS I}

9705 OU Piezo-microfluidic transport system for multi-targets biochip detections [9705-30]

\section{SESSION $8 \quad$ APPLICATIONS II}

9705 0X Microfluidic in-channel multi-electrode platform for neurotransmitter sensing [9705-33]

$97050 Z$ Single-bead arrays for fluorescence-based immunoassays on capillary-driven microfluidic chips [9705-35]

\section{SESSION $9 \quad$ APPLICATIONS III}

970511 Development of automated high throughput single molecular microfluidic detection platform for signal transduction analysis [9705-37] 
SESSION 10 APPLICATIONS IV

970514 Modular microfluidic cartridge-based universal diagnostic system for global health applications [9705-40]

970516 Universal lab-on-a-chip plafform for complex, perfused 3D cell cultures [9705-42]

POSTER SESSION

9705 1A Development of microfluidic-based cell collection devices for in vitro and in vivo use [9705-47] 
Proc. of SPIE Vol. $9705970501-6$

Downloaded From: https://www.spiedigitallibrary.org/conference-proceedings-of-spie on 26 Apr 2023 Terms of Use: https://www.spiedigitallibrary.org/terms-of-use 


\section{Authors}

Numbers in the index correspond to the last two digits of the six-digit citation identifier (CID) article numbering system used in Proceedings of SPIE. The first four digits reflect the volume number. Base 36 numbering is employed for the last two digits and indicates the order of articles within the volume. Numbers start with 00, 01, 02, 03, 04, 05, 06, 07, 08, 09, OA, OB...0Z, followed by 10-1Z, 20-2Z, etc.

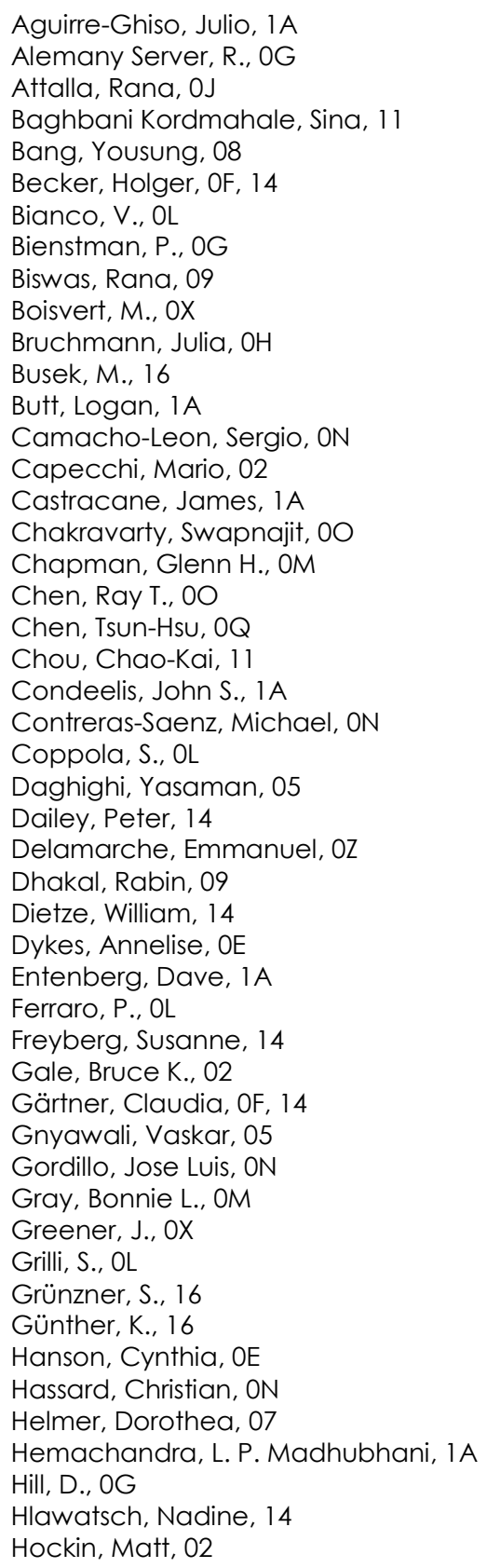

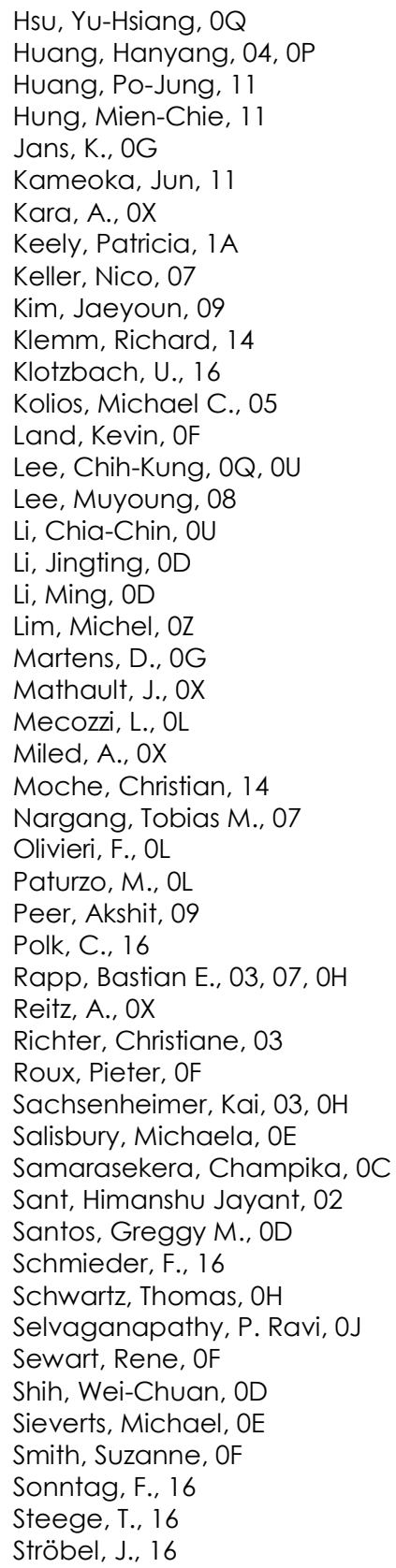


Strohm, Eric M., 05

Strohmayer, Matthew, IA

Tang, Naimei, 00

Temiz, Yuksel, OZ

Tessier, F., OX

Tew, Karen, OE

Todino, M., OL

Tsai, Scott S. H., 05

Vargas-Chacon, Rafael, ON

Vargis, Elizabeth, OE

Vespini, $\mathrm{V} ., \mathrm{OL}$

Wang, Hsin-Hu, OQ

Wang, Pei-Wen, OU

Wang, Qian, 04

Wei, Kang, 04, OP

White, Wallace, 14

Won, Yong Hyub, 08

Yamaguchi, Hirohito, 11

Yan, Hai, $0 \mathrm{O}$

Yeow, John T. W., OC

Zhao, Fusheng, OD

Zhao, Yi, 04, OP

Zou, Yi, 00 


\title{
Conference Committee
}

\author{
Symposium Chairs
}

James G. Fujimoto, Massachusetts Institute of Technology

(United States)

R. Rox Anderson, Wellman Center for Photomedicine, Massachusetts General Hospital (United States) and Harvard School of Medicine (United States)

Program Track Chairs

Tuan Vo-Dinh, Fitzpatrick Institute for Photonics, Duke University (United States)

Anita Mahadevan-Jansen, Vanderbilt University (United States)

Conference Chairs

Bonnie L. Gray, Simon Fraser University (Canada)

Holger Becker, microfluidic ChipShop GmbH (Germany)

Conference Program Committee

Brian W. Anthony, Massachusetts Institute of Technology (United States)

Yolanda Fintschenko, LabSmith, Inc. (United States)

Bruce K. Gale, The University of Utah (United States)

Albert K. Henning, Aquarian Microsystems (United States)

Yu-Cheng Lin, National Cheng Kung University (Taiwan)

Yuehe Lin, Pacific Northwest National Laboratory (United States)

Ciara K. O'Sullivan, Universitat Rovira i Virgili (Spain)

Ian Papautsky, University of Cincinnati (United States)

Bastian E. Rapp, Karlsruher Institut für Technologie (Germany)

Thomas Stieglitz, Albert-Ludwigs-Universität Freiburg (Germany)

Sindy Kam-Yan Tang, Stanford University (United States)

Albert van den Berg, MESA+ Institute for Nanotechnology

(Netherlands)

Wanjun Wang, Louisiana State University (United States)

Bernhard H. Weigl, PATH (United States)

\section{Session Chairs}

1 Microfluidic Devices I

Bonnie L. Gray, Simon Fraser University (Canada)

Holger Becker, microfluidic ChipShop GmbH (Germany) 
2 Manufacturing I

Himanshu J. Sant, The University of Utah (United States)

3 Microfluidic Devices II

P. Ravi Selvaganapathy, McMaster University (Canada)

4 Medical Devices I

Swapnajit Chakravarty, Omega Optics, Inc. (United States)

5 Manufacturing II

Christiane Richter, Karlsruher Institut für Technologie (Germany)

6 Optofluidics

Daniel Hill, Universitat de València (Spain)

7 Applications I

Holger Becker, microfluidic ChipShop GmbH (Germany)

8 Applications II

Amy Shen, Okinawa Institute of Science and Technology (Japan)

9 Applications III

Thomas Gervais, Ecole Polytechnique de Montréal (Canada)

10 Applications IV

Bonnie L. Gray, Simon Fraser University (Canada)

Panel Discussion: Prospects and Future of Microfluidics

Holger Becker, (Moderator) microfluidic ChipShop GmbH (Germany)

Proc. of SPIE Vol. $9705970501-10$ 


\section{Introduction}

Welcome to the proceedings for the 2016 SPIE Photonics West Conference: Microfluidics, BioMEMS, and Medical Microsystems. The conference is going strong in its 14 th year.

This year, we had 32 presented papers covering devices, fabrication, and applications of microfluidics, optofluidics, and bioMEMS. This included 9 invited papers from leaders in the field covering topics such as rare and challenging cell separation and identification; 3-D printing; biosensors; accoustophoresis; and personalized medicine. Each invited talk anchored a session of contributed papers given by researchers from many different institutions and companies from all over the world.

The Panel Discussion on Monday evening attracted panelists from Bay Area companies and elsewhere, and was very well attended. The audience fully participated asking questions and joining in the lively discussion on the current status of microfluidics and the future that we have to look forward to next year and beyond.

Also announced during the Panel Discussion was the winner of the Student Paper Award. The contest was once again a success, showcasing up and coming talent from the undergraduate through the doctoral student levels. Rabin Dhakal from lowa State University (United States) won the Best Student Paper Award with his paper entitled "Transfer molding processes for nanoscale patterning of poly-Llactic acid (PLLA) films" [9705-8] co-authored by Akshit Peer, Rana Biswas, and Jaeyoun Kim.

We look forward to seeing everyone next year and further growing the size and success of the conference.

Holger Becker Bonnie L. Gray 
Proc. of SPIE Vol. $9705970501-12$

Downloaded From: https://www.spiedigitallibrary.org/conference-proceedings-of-spie on 26 Apr 2023 Terms of Use: https://www.spiedigitallibrary.org/terms-of-use 